Article

\title{
Variation of Routine Soil Analysis When Compared with Hyperspectral Narrow Band Sensing Method
}

\author{
José A. M. Demattê ${ }^{1}$, Peterson R. Fiorio ${ }^{2}$ and Suzana R. Araújo ${ }^{1, *}$ \\ 1 Department of Soil Science, University of São Paulo, Av. Pádua Dias 11, Piracicaba, São Paulo, \\ Brazil; E-Mail: jamdemat@esalq.usp.br \\ 2 Department of Biosystems Engineering, University of São Paulo, Av. Pádua Dias 11, Piracicaba, \\ São Paulo, Brazil; E-Mail: fiorio@esalq.usp.br \\ * Author to whom correspondence should be addressed; E-Mail: sraraujo@esalq.usp.br; \\ Tel.: +55-019-3417-2453; Fax: +55-019-3417-2110.
}

Received: 25 June 2010; in revised form: 29 July 2010 / Accepted: 30 July 2010 /

Published: 24 August 2010

\begin{abstract}
The objectives of this research were to: (i) develop hyperspectral narrow-band models to determine soil variables such as organic matter content (OM), sum of cations $(\mathrm{SC}=\mathrm{Ca}+\mathrm{Mg}+\mathrm{K})$, aluminum saturation $(\mathrm{m} \%)$, cations saturation $(\mathrm{V} \%)$, cations exchangeable capacity (CEC), silt, sand and clay content using visible-near infrared (Vis-NIR) diffuse reflectance spectra; (ii) compare the variations of the chemical and the spectroradiometric soil analysis (Vis-NIR). The study area is located in São Paulo State, Brazil. The soils were sampled over an area of 473 ha divided into grids $(100 \times 100 \mathrm{~m})$ with a total of 948 soil samples georeferenced. The laboratory RS data were obtained using an IRIS (Infrared Intelligent Spectroradiometer) sensor (400-2,500 nm) with a 2-nm spectral resolution between 450 and 1,000 nm and 4-nm between 1,000 and 2,500 nm. Satellite reflectance values were sampled from corrected Landsat Thematic Mapper (TM) images. Each pixel in the image was evaluated as its vegetation index, color compositions and soil line concepts regarding certain locations of the field in the image. Chemical and physical analysis (organic matter content, sand, silt, clay, sum of cations, cations saturation, aluminum saturation and cations exchange capacity) were performed in the laboratory. Statistical analysis and multiple regression equations for soil attribute predictions using radiometric data were developed. Laboratory data used 22 bands and 13 "Reflectance Inflexion Differences, RID" from different wavelength intervals of the optical spectrum. However, for TM-Landsat six bands were used in analysis (1, 2, 3, 4, 5, and 7).
\end{abstract}


Estimations of some tropical soil attributes were possible using laboratory spectral analysis. Laboratory spectral reflectance (SR) presented high correlations with traditional laboratory analyses for the soil attributes such as clay $\left(\mathrm{R}^{2}=0.84, \mathrm{RMSE}=3.75\right)$ and sand $\left(\mathrm{R}^{2}=0.85\right.$, RMSE $=3.74$ ). The most sensitive narrow-bands in modeling (using 474 observations) these attributes were B8 (1,350-1,417 nm), B10 (1,417-1,449 nm), B11 (1,449-1,793 nm), B15 (1,927-2,102 nm), B16 (2,101-2,139 nm), and B17 (2,139-2,206 nm); B7 (975-1,350 nm), B10, B11, B16, B19 (2,206-2,258 nm) and B21 (2,258-2,389 nm) for clay and sand, respectively. The bands selected to model sand and clay, by orbital data, were 3, 5 and 7 of TM-Landsat-5 and 2, 5 and 7 sand and clay, respectively. The use of soil analysis methodology by ground remote sensing constitutes an alternative to traditional routine laboratory analysis.

Keywords: remote sensing; soil reflectance; soil attributes

\section{Introduction}

Soil chemical properties are neither static nor homogeneous in space and time. Acquiring spatial soil variability analytically in the laboratory is time- and cost-intensive, which is especially true for large-scale applications with a necessarily high number of soil samples [1,2]. Its high costs has been hindered the introduction of precision agriculture in several parts of the world [3]. Precision farming needs the identification of even short- or medium-term changes in the nutrient status of the soils. Wetterlind et al. [4] proposed successfully the use of near infrared (NIR) spectroscopy to improve soil mapping at the farm scale. Finally, the development of actual physico-chemical soil maps can be identified as one major limitation for continuous soil monitoring at farm level [5]. Also, large amounts of chemical residues are produced with the conventional analysis. In a recent publication, Cantarela et al. [6] demonstrated that routine soil analysis, determined by different laboratories, may have its varied, while using the same methodology.

Visible/near-infrared diffuse reflectance spectroscopy (VNIRS) has proven to be a promising technique for the investigation of various soil properties. Compared to conventional analytical methods, VNIRS is faster, cheaper and non-destructive, requires less sample preparation, with less or no chemical reagents, is highly adaptable to automated and in situ measurements, and has the potential to analyze various soil properties simultaneously $[7,8,9]$.

Soil attributes have close physical relationships with the reflected energy, as demonstrated in the last decades [9-15]. The bidirectional reflectance of soils is affected in a complex manner by the inherent spectral characteristics of the current mineral components, the organic matter, and the moisture contents [16]. An overview of factors influencing soil reflectance is given by Ben Dor et al. [17]. These results lead us to question as others spectral sensing researchers [11]: "Can remote sensing substitute the soil analysis?” This question was raised based on years of studies in spectral information about soil quantification. Afterwards, this was also mentioned by [18,19], for whom some soil attributes analysis could be substituted. But, until then, laboratory analysis has been considered as our "real" truth. With 
the paper of Cantarela et al. [6] came the question: "is this the real truth?" No doubt that this is the most important reference for us, but could the VNIRS technology be inserted as an assistance to traditional analysis? There are few manuscripts that compared the variations of the traditional soil analysis with the results obtained by sensor methods [8,19-21]. Usually, the papers compare directly the laboratory analysis with spectral sensing, but do not inform the variation of the data.

In this context, the goal of this research is to develop hyperspectral narrow-band models to determine soil variables such as organic matter content $(\mathrm{OM})$, sum of cations $(\mathrm{SC}=\mathrm{Ca}+\mathrm{Mg}+\mathrm{K})$, aluminum saturation ( $\mathrm{m} \%$ ), cations saturation (V\%), cations exchangeable capacity (CEC), silt, sand and clay content. Prediction models of soil properties have shown a high potential [22-24]. Since reflected energy has a strong physical relation with several soil attributes (e.g., clay, sand), we expect that spectral information present an accurate model that allow quantifying these soil attributes. Furthermore, it were compared the variations of the chemical soil analysis and the spectroradiometric soil analysis.

\section{Study Area and Soil Analysis}

\subsection{Description of the Study Area and Soil Sampling}

The area was located in Barra Bonita Country, southeast of São Paulo, Brazil and covers an area of 473 ha. Regular $100 \times 100$ m grids were used to divide the field. All areas sampled were bare soil. In a total of 948 soil samples were georeferenced using the differential global positioning system. The collected soil samples were sent for chemical and physical analysis in the laboratory. The texture groups of the soils were defined according to Empresa Brasileira de Pesquisa Agropecuária [25]. The contents of $\mathrm{Ca}, \mathrm{Mg}, \mathrm{K}$, and the sum of the bases (SC) were determined according to Raij et al. [26], Organic matter, total and effective acidity, $\mathrm{pH}$ in water and in $\mathrm{KCl}, \mathrm{CEC}$, the values of base saturation (V\%) and $\mathrm{Al}(\mathrm{m} \%)$ were determined according to EMBRAPA [27].

\subsection{Methodology Procedure}

The experiment was divided in three phases: (a) collection of soil samples from the field; collection of the spectral data of these samples using a laboratory sensor; collection of spectral data from satellite sensors; determination of soil attributes using laboratory analysis; (b) determination of statistical models that correlated spectral data with each soil attribute from both, laboratory and satellite sensors; and (c) validation of the models obtained.

\section{Spectral Data Acquisition}

\subsection{Laboratory Spectral Data Acquisition}

Laboratory spectral data were obtained in a controlled environment using the Infra-Red Intelligent Spectroradiometer (IRIS) sensor [28], with a spectral resolution of $2 \mathrm{~nm}$ (from 350 to 1,000 nm) and 4 $\mathrm{nm}$ (from 1,000 to 2,500 nm), which included visible and infrared wavelengths. Therefore, soil samples were dried in an oven at $45^{\circ} \mathrm{C}$ for $24 \mathrm{~h}$, according to Henderson et al. [29], and were placed on $9 \mathrm{~cm}$ diameter petri plates. Three replicate scans of each soil sample were taken to increase the soil 
surface scanned by the sensor and the mean spectral curve was used for analysis. The scanning geometry was set in a perpendicular positioning with relation to the sample according to Demattê and Garcia [30] and Demattê et al. [31]. The experimental setting allowed to measure a bidirectional reflectance factor, as defined by [32] as the ratio between the sample's reflected spectral flux and a standard spectral flux (a $\mathrm{BaSO}_{4}$ plate under the same conditions). The absolute white reference used for calibration for the instrument was a Spectralon ${ }^{\circledR}$ white reference plate.

\subsection{Satellite Spectral Data Acquisition}

ATM-Landsat 5 image, bands 1, 2, 3, 4, 5, and 7, was used to obtain satellite level data. The Spring program developed by the Brazilian National Space Research Institute, INPE [33] was utilized to set up and manipulate the database. Spring is the newest generation of geoprocessing programs conceived for object oriented programming with multiple functions and algorithms for processing georeferenced databases [34]. Digital number values (DN) obtained from the TM Landsat images were transformed into spectral reflectance (SR) values and properly adjusted for atmospheric effects $[18,35]$. Thus the image was corrected, band-to-band, where the atmospheric effects were eliminated, and then digital numbers were converted into "real" SR values [36]. For this purpose, digital number values were first normalized to "top of atmosphere" apparent reflectance and then corrected for Rayleigh scattering and ozone absorption by using the 5S (Satellite Signal Simulation within the Solar Spectrum) radiate transfer code simulation [37,38] described in detail by [36]. The DN refers to the same point of soil sampling in the field that has been georeferenced and was extracted by a "pixel reading" algorithm [39]. Geometric correction was necessary to adjust the real image position. Hence, planialtimetric maps (scale 1:10,000), were used. In addition, points obtained in the field with the Global Positioning System (GPS) with submeter accuracy were used. In order to maintain the pixel value as close as possible to its original value, an interpolation process, called nearest neighbor method [40] was performed, correcting only scale distortions, displacement or rotation between the image and the terrestrial projection.

Afterwards each pixel was evaluated as the bare soil significance $[41,42]$. The methodology to identify bare soils in the image consists of vegetation indices, soil line concepts, image composition and soil genesis information regarding certain locations of the field in the image [41]. The pixel is only collected and considered as bare soil, if all concepts are accepted, i.e., when all indices demonstrated bare soil. The Normalized Difference Vegetation Index (NDVI) refers to the band ratio between red $(R)$ and the near-infrared reflectance [43]. In the Spring program, the NDVI index was calculated by the equation $\mathrm{C}=\mathrm{G}[(\mathrm{A}-\mathrm{B}) /(\mathrm{A}+\mathrm{B})]+\mathrm{O}$, where $\mathrm{A}$ refers to near infrared band; $\mathrm{B}=$ red band; $\mathrm{G}=$ image gain, and $\mathrm{O}=$ image offset. Moreover, to increase SR contrast between vegetation and soil, NDVI was partially compensated for illumination, surface declivity, and geometry [44]. Some vegetation indexes are denominated of the "soil line". The soil line is a linear relationship between the near infrared (NIR) and $R$ reflectance of bare soil as characterized by slope and intercept parameters [45]. The data can be observed on a bidimensional graph formed by both, visible and NIR bands [46]. Thus, vegetation present in a studied image will be, theoretically, proportional to the Euclidean orthogonal distance on this "soil line". Reciprocally, Euclidean distance, based on vegetation index, has a complementary orthogonal index, which relates to soil optical properties with less vegetation [47]. Garey and Sabbagh [48] describe 
that remotely sensed estimations of soil surface properties can lead to improved representation of spatial heterogeneity. The methodology used in this paper evaluates the pixel as its vegetation index, color compositions and soil line concepts [18] regarding certain locations of the field in the image.

\section{Statistical Analysis}

An automated statistical system was used to identify the best bands for each model [49]. In total of 948 samples obtained from the surface and under-surface layer, 474 were randomly separated regardless of the sampling layer for generating the models (Figure 1). The remaining 474 samples were used to test the model (validation phase). The data was submitted to correlation analysis between soil attributes and their respective SR characteristics (predictor variables), using the Statistical Analysis System software [49].

Figure 1. Representation of the study area: 474 sampling points and 948 soil samples collected with a regular $100 \times 100$ m grid.

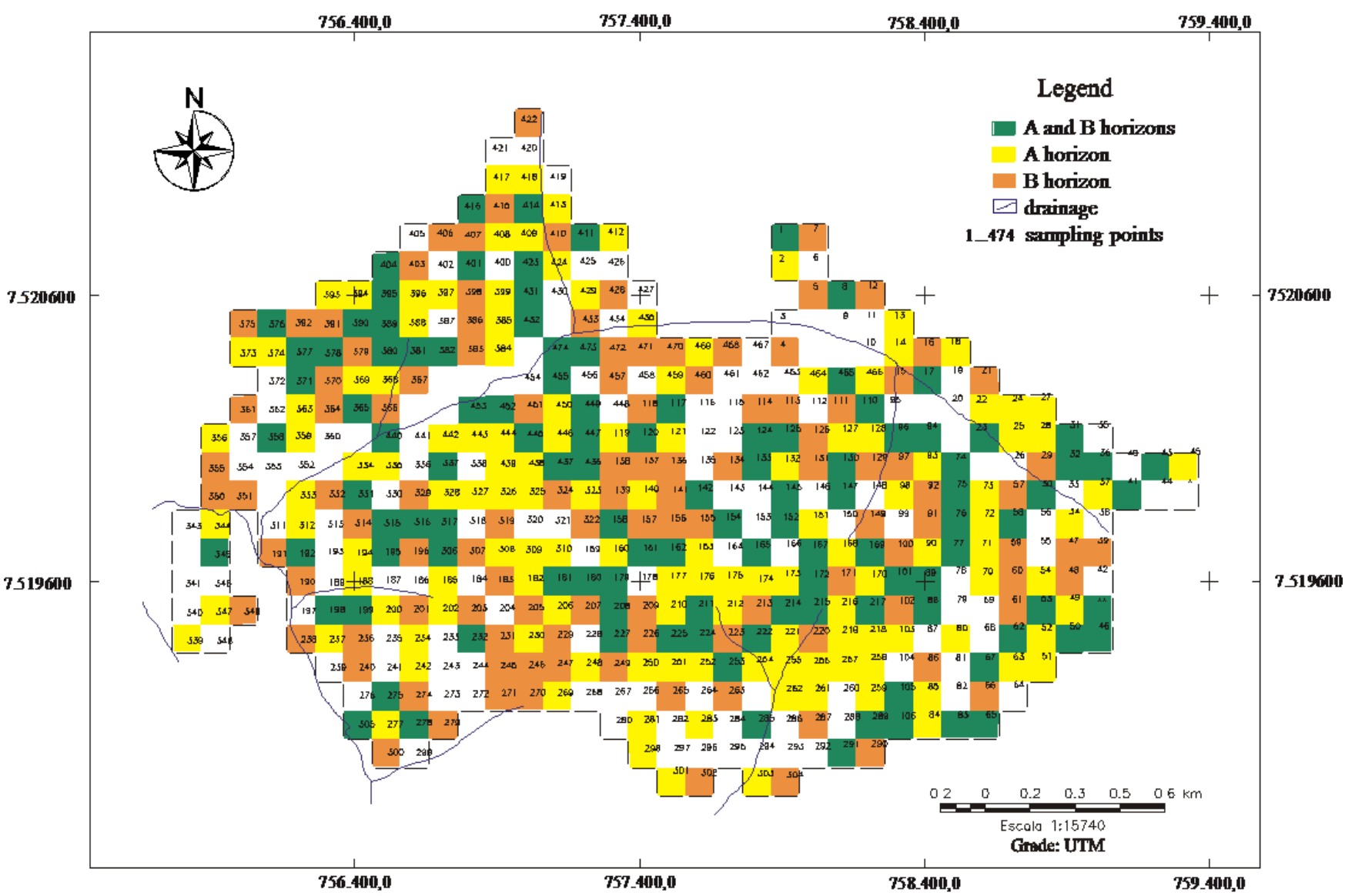

*Green, yellow and orange represent the selected points used to generate the chemical and physical models of soil attributes.

The soil variables used in the correlation with spectral characteristics were: organic matter content $(\mathrm{OM})$, sand, silt, clay, sum of cations $(\mathrm{SC}=\mathrm{Ca}+\mathrm{Mg}+\mathrm{K})$, cations saturation $(\mathrm{V} \%=[\mathrm{SC} / \mathrm{CEC}] * 100)$, aluminum saturation $(\mathrm{m} \%)$ and cation exchange capacity (CEC). The laboratory sensor presented a larger number of bands, allowing a higher radiometric resolution. Thus, to make the statistics easier, the following 22 specific wavelengths from laboratory sensor were selected according to Nanni and 
Demattê [50]: B1: 450-481, B2: 481, B3: 481-596, B4: 596-710, B5: 710-814, B6: 814-975, B7: 975-1,350, B8: 1,350-1,417, B9: 1,417, B10: 1,417-1,449, B11: 1,449-1,793, B12: 1,793-1,831, B13: 1,865-1,927, B14: 1,927, B15: 1,927-2,102, B16: 2,101-2,139, B17: 2,139-2,206, B18: 2,206, B19: 2,206-2,258, B20: 2,258, B21: 2,258-2,389, B22: 2,389-2,498 nm. The bands selection was based on the empirical observation of the analyzed spectrum, which showed SR curve inflections, convex and concave portions, and variation of reflectance intensity in all spectrum; the literature observations that depicted the correct wavelengths that have relationships with soil attributes [10,30,51] and the wavelengths characterized by a strong inflection, such as iron oxides (481 nm), water and $\mathrm{OH}$ groups $(1,417$ and 1,927 $\mathrm{nm})$, kaolinite $(2,206 \mathrm{~nm})$, and gibbsite $(2,265 \mathrm{~nm})$. Moreover, based on the difference between reflectance value at the highest and lowest points of inflection (or Amplitude of spectral data at this range), 13 reflectance inflection difference were too selected (demonstrating the height of the curve between peak and valley) [42]. For ATM-Landsat six bands were used in analysis. Initially, predictive variables for laboratory and orbital data were selected using the SAS program. This procedure was used to determine which variables from the 22 bands (B) (laboratory sensor), presented the higher or lower potential for the models' development [18].

Through the use of SAS regression function, correlations between radiometric data and soil attributes were determined. To prevent overlapping of two or more variables, independent variables or radiometric characteristics were evaluated for co-linearity, avoiding biases in the analysis. Then, multiple linear regression equations were developed for each attribute, using the SAS multivariate analysis component (STEPWISE). After that, these equations were tested with the reflectance data of remaining samples (474) that were not used to build the models. Thus, it was possible to produce a database with soil attribute values determined in the laboratory by traditional methods (DV) and values estimated by radiometry (EV). DV and EV were compared by Tukey's test $(P<0.05)$.

It was created in 1984 a soil proficiency test in Brazil to encourage the uniform use of the methods routinely used for soil analysis in this country, improving the analytical quality of the results. The proficiency test has been running now for more than 20 years and comprises 89 public and private laboratories. The assessment of the performance of routine laboratory analysis in Brazil was presented in 2000 and published afterwards by Cantarela et al. [6]. One of the objectives was the standardization of the analysis results. Samples from the same soils were sent every year to the laboratories that are part of the program. The average (x), standard deviation (s), coefficient of variation (CV), minimum and maximum values for each routinely analyzed soil attribute were obtained after a statistical treatment. Thus, a laboratory was considered in the standard when its results lied within the minimum and maximum values. Based on these results, a tolerance interval (minimum and maximum values) was generated for DV. When EV presented values within this tolerance interval, the value was considered satisfactory. For example, for the sample identified with the number 454, the sand attribute presented a value of $530 \mathrm{~g} \mathrm{~kg}^{-1}$ (DV). If we apply the $\pm 20 \%$ criteria [6], the minimum and maximum values of $424 \mathrm{~g} \mathrm{~kg}^{-1}$ and $636 \mathrm{~g} \mathrm{~kg}^{-1}$, respectively, are acceptable. As the EV (determined using equations based on reflectance) was $529 \mathrm{~g} \mathrm{~kg}^{-1}$, it can be considered in "agreement" or "within the interval" established by laboratories. Since no basic rule for tolerance variation of soil samples exists, other intervals were established for comparison and discussion. The compared EV to DV, were classified as follows: $0-20 \%$, very good; $21-30 \%$, good; $31-40 \%$, poor and $>41 \%$, very poor. DV and EV were also correlated for sand, clay, organic matter, SC and CEC attributes. It was determined the 
quadratic determination coefficient $\left(\mathrm{R}^{2}\right)$ in order to estimate soil attributes by spectral reflectance and traditional methods.

\section{Results and Discussion}

\subsection{Soil Attributes Based on the Spectral Response Obtained by Sensor in Laboratory}

Equations were established to estimate soil attributes with the SR of the matrix data for soils. The equations for $\mathrm{m} \%$ and CEC presented, respectively, with the largest and smallest number of variables between bands and heights (Table 1). The technique of multivariate analysis allowed the selection of the bands which had better correlations with each attribute, agreeing with Huete \& Escadafal [52].

The $t$-test was used as a preliminary result to compare the DV (determined values) of soil attribute obtained by soil chemical analysis and its EV (estimated values) obtained using the models (Table 1). It was found no significant differences between the traditional analysis and that obtained by the sensor (Table 2). These results partially differ from those of Nanni \& Demattê [50] where the averages between DV and EV for sand and OM, showed significant differences. Moreover, the results for clay and silt obtained by these authors confirm the good results of this research.

In order to get better evaluation of the data, a criterion that compares DV and EV punctually was used in the 474 samples (Table 3). Each soil sample was evaluated individually. For example, sand values: sample number 102 had a determined content of $720 \mathrm{~g} \mathrm{~kg}^{-1}$. Using range interval of confidence extracted from Cantarella [6], 20\%, we determined a range interval, in which the error would be accepted. In case the minimum and maximum acceptable spectral model estimated value would be $571 \mathrm{~g} \mathrm{~kg}^{-1}$ to $869 \mathrm{~g} \mathrm{~kg}^{-1}$, respectively. The estimated value for the same soil sample, using spectral laboratory model was $527 \mathrm{~g} \mathrm{~kg}^{-1}$. In this case the estimated value was "below" the confidence range interval. Thus, table 3 presents the percentage of sample classified.

This criterion was based on studies carried out with soil samples in routine laboratories according to Cantarella et al. [6]. A high determination coefficient $\left(\mathrm{R}^{2}\right)$ was found for sand (84\%) and clay (74\%), i.e., 396 and 351 of the 474 samples tested were within the tolerance variation interval proposed by the soil analysis in laboratories. A 52\% agreement was observed for silt. However, in practice, silt can be determined by subtraction, since sand and clay were adequately estimated, as done in the laboratory according to Raij et al. [26]. Similarly to silt, CEC showed an 51\% agreement (Table 3). SC, OM, m\% and $\mathrm{V} \%$ presented low rates of agreement. 
Table 1. Multiple regression equations to estimate soil attributes by laboratory sensor using 22 bands and 13 heights (using 474 observations).

\begin{tabular}{|c|c|c|}
\hline Variables & Multiple equations & $\mathrm{r}^{2(2)}$ \\
\hline Total sand & $\begin{array}{l}409.59806+(-3346.58558 * \mathrm{H} 3)+(20887 * \mathrm{~B} 11)+(-14543 * \mathrm{~B} 16)+(-10890 * \mathrm{H} 7)+(-9824.77554 * \mathrm{~B} 19)+(-19212 * \mathrm{~B} 10)+(13431 * \mathrm{H} 12) \\
+(26675 * \mathrm{~B} 21)+(-3035.10462 * \mathrm{~B} 7)\end{array}$ & 0.8174 \\
\hline Silt & $129.83933+(-1943.40654 * \mathrm{H} 10)+(-2624.05031 * \mathrm{H} 9)+(1916.57891 * \mathrm{H} 8)+(2353.36975 * \mathrm{H} 5)+(2162.49950 * \mathrm{H} 1)$ & 0.5672 \\
\hline Clay & $\begin{array}{l}376.23728+(4092.67466 * \mathrm{H} 3)+(10972 * \mathrm{H} 7)+(1409.95843 * \mathrm{H} 2)+(-25070 * \mathrm{~B} 11)+(23006 * \mathrm{~B} 16)+(-23085 * \mathrm{H} 11)+(30702 * \mathrm{~B} 10)+ \\
(-19095 * \mathrm{~B} 17)+(8651.36527 * \mathrm{H} 12)+(-2273.14097 * \mathrm{H} 1)+(-4697.25743 * \mathrm{~B} 15)+(-6041.71261 * \mathrm{~B} 8)\end{array}$ & 0.8570 \\
\hline $\begin{array}{c}\text { Organic } \\
\text { matter }\end{array}$ & $29.00804+(-141.76148 * \mathrm{H} 2)+(-225.82107 * \mathrm{H} 3)+(-517.81987 * \mathrm{H} 13)+(746.61657 * \mathrm{~B} 1)+(-476.15447 * \mathrm{~B} 3)+(332.27114 * \mathrm{H} 5)$ & 0.2988 \\
\hline $\begin{array}{l}\text { Sum of } \\
\text { cations }\end{array}$ & $455.20858+(-25577 * \mathrm{H} 11)+(23797 * \mathrm{H} 12)+(-3138.20686 * \mathrm{H} 3)+(5295.62046 * \mathrm{H} 1)+(-7983.39289 * \mathrm{H} 5)+(4108.62012 * \mathrm{H} 8)$ & 0.6345 \\
\hline Bases sat. & $\begin{array}{l}79.81023+(-1016.67292 * \mathrm{~B} 1)+(2892.46819 * \mathrm{~B} 8)+(-2560.16606 * \mathrm{~B} 7)+(-1067.64273 * \mathrm{H} 4)+(3300.62458 * \mathrm{H} 12)+(-919.36419 * \mathrm{H} 10) \\
+(488.23896 * \mathrm{H} 3)+(-1480.00508 * \mathrm{H} 11)\end{array}$ & 0.5055 \\
\hline $\begin{array}{l}\text { Aluminum } \\
\text { sat. }\end{array}$ & $\begin{array}{l}-22.14932+(3801.42681 * \mathrm{H} 5)+(-2050.46588 * \mathrm{H} 8)+(2082.39681 * \mathrm{~B} 1)+(-6728.15162 * \mathrm{~B} 3)+(-4326.51343 * \mathrm{~B} 10)+(-699.51724 * \mathrm{H} 3) \\
+(6123.58955 * \mathrm{~B} 2)+(1570.79618 * \mathrm{H} 13)+(3540.68221 * \mathrm{H} 1)+(960.41493 * \mathrm{H} 2)+(-995.46185 * \mathrm{H} 12)+(1273.60350 * \mathrm{~B} 11)+ \\
(2584.29549 * \mathrm{~B} 9)\end{array}$ & 0.6802 \\
\hline CEC & $753.20475+(-32058 * \mathrm{H} 11)+(26746 * \mathrm{H} 12)+(-4921.96650 * \mathrm{H} 3)+(5686.79082 * \mathrm{H} 1)$ & 0.5358 \\
\hline
\end{tabular}

${ }^{(2)}$ Significant at $p<0.05$; B1 (450-481), B2 (481), B3 (481-596), B4 (596-710), B5 (710-814), B6 (814-975), B7 (975-1350), B8 (1350-1417), B9 (1417), B10 (1417-1449), B11 (1449-1793), B12 (1793-1831), B13 (1865-1927), B14 (1927), B15 (1927-2102), B16 (2101-2139), B17 (2139-2206), B18 (2206), B19 (2206-2258), B20 (2258), B21 (2258-2389), B22 (2389-2498) in nm;

Table 2. Comparison of mean (t-test) of soil attributes values determined by traditional analysis and by sensor (models).

\begin{tabular}{|c|c|c|c|c|c|c|c|c|}
\hline & Sand & Silt & Clay & Organic matter & Sum of cations & CEC & V\% & $\mathbf{m \%}$ \\
\hline & 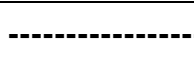 & -....... & -1 & - & \multicolumn{2}{|c|}{------mmol $\mathrm{dm}^{-3}$} & \multicolumn{2}{|c|}{ 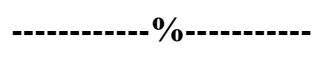 } \\
\hline $\mathrm{DV}^{(1)}$ & $701.10 \mathrm{a}^{(3)}$ & $52.64 \mathrm{a}$ & $256.33 a$ & $13.26 \mathrm{a}$ & $223.23 \mathrm{a}$ & $440.82 \mathrm{a}$ & $45.18 \mathrm{a}$ & $22.76 \mathrm{a}$ \\
\hline $\mathrm{EV}^{(2)}$ & $691.01 \mathrm{a}$ & $52.78 \mathrm{a}$ & $244.56 \mathrm{a}$ & $13.35 \mathrm{a}$ & $212.50 \mathrm{a}$ & $428.70 \mathrm{a}$ & $45.15 \mathrm{a}$ & $23.70 \mathrm{a}$ \\
\hline
\end{tabular}

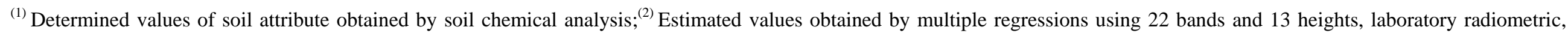
IRIS sensor; ${ }^{(3)} t$ Student test, $1 \%$ significance, averages with the same letters in column do not differ. 
Table 3. Number of samples that used multiple regression equations to develop spectral models to determine soil attributes contents.

\begin{tabular}{|c|c|c|c|c|c|c|c|c|}
\hline \multirow{3}{*}{ Range $^{\text {(a) }}$} & \multicolumn{2}{|l|}{ Sand } & \multicolumn{2}{|l|}{ Silt } & \multicolumn{2}{|l|}{ Clay } & \multicolumn{2}{|l|}{$\mathrm{OM}^{(\mathrm{c})}$} \\
\hline & $20.0^{(\mathrm{a})}$ & & $36.8^{(a)}$ & & $27.8^{(\mathrm{a})}$ & & $20.15^{(a)}$ & \\
\hline & Samples ${ }^{(b)} \%$ & & Samples & $\%$ & Samples & $\%$ & Samples & $\%$ \\
\hline Below & 17 & 4 & 67 & 14 & 55 & 12 & 120 & 25 \\
\hline In & 396 & 84 & 245 & 52 & 351 & 74 & 163 & 34 \\
\hline \multirow[t]{2}{*}{ Above } & 61 & 13 & 162 & 34 & 68 & 14 & 191 & 40 \\
\hline & $\mathrm{SC}^{(\mathrm{d})}$ & & $\mathrm{V}^{(\mathrm{e})}$ & & $\mathrm{m}^{(\mathrm{f})}$ & & $\mathrm{CEC}^{(\mathrm{g})}$ & \\
\hline \multirow[t]{2}{*}{ Range $^{(a)}$} & $28.34^{(\mathrm{a})}$ & & $4.08^{(a)}$ & & $31.80^{(\mathrm{a})}$ & & $24.54^{(\mathrm{a})}$ & \\
\hline & Samples (b) & $\%$ & Samples & $\%$ & Samples & $\%$ & Samples & $\%$ \\
\hline Below & 115 & 24 & 182 & 38 & 143 & 30 & 91 & 19 \\
\hline In & 178 & 38 & 49 & 10 & 137 & 29 & 241 & 51 \\
\hline Above & 181 & 38 & 243 & 51 & 194 & 41 & 142 & 30 \\
\hline
\end{tabular}

(a) Range interval of confidence, extracted from the IAC Laboratory Quality Control Programs Center of Soil Analysis [33];

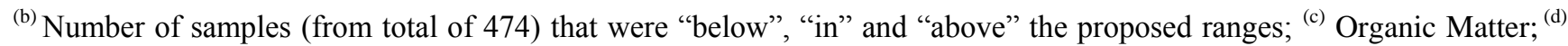
Sum of Cation; ${ }^{(\mathrm{e})}$ Base saturation; ${ }^{(\mathrm{f})}$ Aluminum saturation; ${ }^{(\mathrm{g})}$ Cation exchange capacity.

These results demonstrate that there is greater potential for estimating physical parameters such as sand and clay than for chemical parameters, as V\%. There are variations between laboratory soil analyses [53]. To make feasible comparison of these data, the present work suggests using fixed variation intervals as presented in Table 3. For example, the largest number of EV samples in the 0-20\% range, had the best multiple regression equation. The results obtained with the sand equation identified $83.5 \%$ of the samples in this range, followed by clay with $59.8 \%$ and CEC with $41 \%$. The other results have shown a very low percentage (Table 4).

Table 4. Percentage of samples, results in the tolerance range, comparison between relative values ${ }^{(a)}$ of laboratory traditional data (real value) and values obtained by the laboratory spectral models.

\begin{tabular}{|c|c|c|c|c|c|c|c|c|}
\hline & Sand & Silt & Clay & $\mathrm{OM}^{(\mathrm{b})}$ & $\mathrm{SC}^{(\mathrm{c}))}$ & $\mathrm{CEC}^{(\mathrm{d})}$ & $\mathrm{V}^{(\mathrm{e})}$ & $m^{(f)}$ \\
\hline Tolerance Range ${ }^{\text {(a) }}$ & & & & & & & & \\
\hline 0-20\% (very good) & 83.5 & 29.2 & 59.8 & 35.5 & 25.4 & 41.2 & 38.5 & 24.6 \\
\hline $21-30 \%$ (good) & 4.7 & 14.2 & 18.4 & 14.6 & 15.6 & 21.4 & 17.3 & 13.0 \\
\hline $31-40 \%$ (poor) & 1.1 & 10.6 & 9.1 & 13.5 & 9.7 & 12.5 & 11.8 & 11.6 \\
\hline$>41 \%$ (very poor) & 10.8 & 46.1 & 12.7 & 36.4 & 49.3 & 24.9 & 32.3 & 50.7 \\
\hline Total (474 sample) & 100.0 & 100.0 & 100.0 & 100.0 & 100.0 & 100.0 & 100.0 & 100.0 \\
\hline
\end{tabular}

(a) Suggested by present work using the criterion: Relative Value $=\{(\mathrm{DV}-\mathrm{EV}) / \mathrm{DV})\} * 100$ where: DV: determined in laboratory; EV: estimated by laboratory spectral data; ${ }^{(b)}$ Organic Matter; ${ }^{\text {(c) }}$ Sum of Cations; ${ }^{\text {(d) }}$ Cations exchange capacity;

(e) Base saturation; ${ }^{(\mathrm{f})}$ Aluminum saturation.

For the 21-30\% range, considered to be good, the highest agreement was observed for CEC (21.4\%), and in the $31-40 \%$ range, poor, OM was identified with $13 \%$. Agreement for the $0-40 \%$ tolerance interval were $89.3 \%$ for sand, $87.3 \%$ for clay, $75.1 \%$ for CEC, $67.7 \%$ for V\%, and $63.6 \%$ for 
OM. The results above the $40 \%$ interval (very poor) were representative for some attributes, e.g., $\mathrm{m} \%$ with $50.7 \%$, SC with $49.3 \%$, silt with $46.1 \%$. The equations for these attributes probably generated doubtful results and, thus, their use should be avoided. Figure 2 also showed the correlation between the DV and EV, based on the multiple regression equations on Table 1. The highest coefficients of determination $\left(\mathrm{R}^{2}\right)$ were observed for sand $(0.85)$ and clay $(0.84)$. The $\mathrm{R}^{2}$ values of 0.56 for clay and 0.51 for organic matter were determined by Ben-Dor \& Banin [54], with the later value being higher than that obtained in the present study (0.42) (Figure 2).

The coefficients of determination used for SC and CEC were higher than the 0.64 value reported by Ben-Dor \& Banin [54] for CEC. It is interesting to note that in all cases the data estimated by the sensor were above the tolerated variation (Table 3). This finding might be explained by the fact that the models used in the present study were empirical, and the concentration of a given soil constituent was assumed to be proportional to a linear combination of different reflectance intensities and absorption ranges. Similar models have been tested by various authors $[23,54,55]$ for the assessment of $\mathrm{OM}$ and nutrients.

The similar EV and DV values indicated good results for the methodology proposed here due various factors: use of a sensor with high spectral resolution, a high signal-to-noise ratio, spectral data obtained in a constant and controlled environment, and detailed analysis of the soils in the study area. Under these conditions, the sensor detects effects of soil attributes that absorb radiant energy at discrete energy levels. However, divergent results have been noted between studies. The OM value determined in the present study $\left(\mathrm{R}^{2} 0.42\right)$ (Figure 2) was lower than the valued of $\mathrm{OM}\left(\mathrm{R}^{2} 0.79\right)$ found by [18]. But a similar result was reported by [30], with a low correlation for OM (0.45).

The determination coefficient of 0.63 for clay was observed by Coleman et al. [56], while Demattê and Garcia [30] obtained values above 0.75 for this attribute. Nanni and Demattê [50] reported a $\mathrm{R}^{2}$ of 0.91 for clay, while a value of 0.86 was obtained in the present study. These results can be explained by the differences between the methods employed in the various studies. In addition to the use of different equipments, the main divergence lies in the selection of the bands used to develop the models and the soils data analyzed [52]. Instead of using 22 bands, Demattê et al. [57] used 11 bands to evaluate spectral curves of three different soils amended with organic residues derived from the cane sugar industry, with the use of FieldSpec sensor. The accuracy of the stepwise analysis was also measured by the root mean squared error of prediction (RMSE) (Table 5).

$$
R M S E=\sqrt{\frac{1}{N}} \sum_{i=1}^{N}\left(\hat{y}_{i}-y_{i}\right)^{2}
$$

where $\hat{y}_{i}$ represents each predicted value, $y_{i}$ represents each determined value and $N$ the number of samples. The low RMSE values confirmed the good results obtained for sand and clay in this work. Saeys et al. [58] fixed the $\mathrm{R}^{2}$ values between 0.50 and 0.65 indicate the possibility to differ high to low concentrations in model. While values of 0.66 to 0.81 , of 0.82 to 0.90 and $\mathrm{R}^{2}$ values greater than 0.90 indicate quantitative models to predict soil chemical attributes acceptable, good and excellent, respectively. The predictions of soil properties that are considered acceptable can be improve with different strategies of calibration [59]. 
However, even laboratory chemical analysis demonstrates that methodologies are regional as described by the Council on Soil Testing and Plant Analysis (1980). These findings should stimulate discussions about methodologies.

Figure 2. Scatter plot of laboratory determined soil values obtained by routine analysis (Determined Value (Y)) and estimated values obtained with the spectral regression models (Estimated Value $(\mathrm{X})$ ).
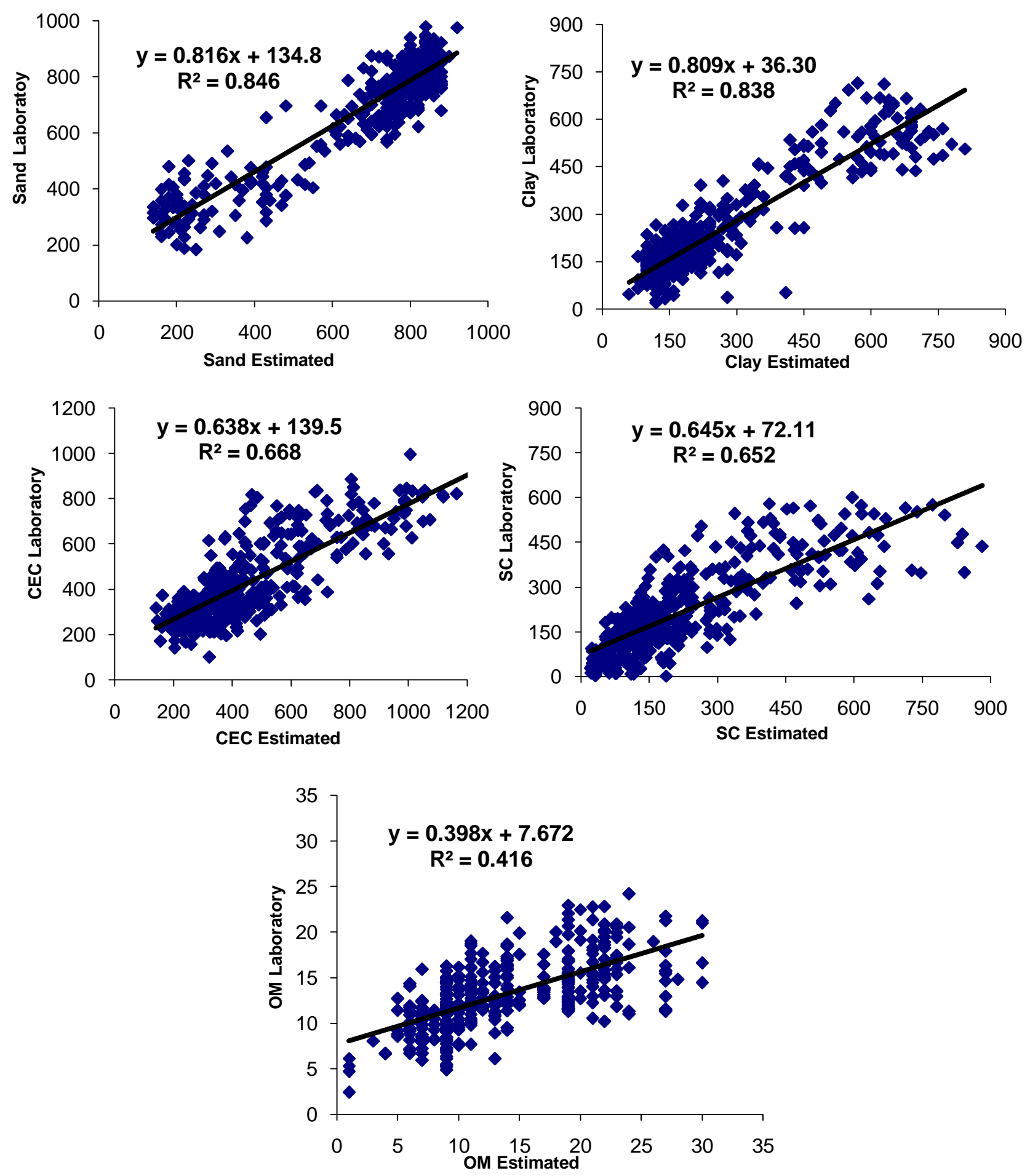
Table 5. Validation results of attributes evaluated in soils by multiple linear regression equations.

\begin{tabular}{cccccc}
\hline Soil variables & OM & Sand & Clay & SC & CEC \\
\cline { 2 - 6 } $\mathbf{R}^{2}$ & 0.417 & 0.846 & 0.839 & 0.653 & 0.668 \\
RMSE & 0.245 & 3.747 & 3.317 & 1.098 & 6.778 \\
\hline
\end{tabular}

\subsection{Estimate of Soil Attributes Based on the Spectral Response Obtained by Orbital Sensor}

It was generated a linear regression equation for each attribute, with $50 \%$ of soil samples from the area studied, in a total of 227 samples (Table 6). We selected, by statistical procedures, three of the six original variables (TM 1, 2, 3, 4, 5 and 7) for sand, silt and clay. It were selected the same bands for sand and silt (3, 5 and 7), differing the band 2 instead of 3 for clay (Table 6). Coleman et al. [60] obtained multiple regression equations for these same attributes, also with three of six variables, however with different bands (sand-2,3 and 7; silt-1,4, and 7; clay- 1,3 and 4). According to these authors, the highest coefficient of determination was 0.4 for clay and less than 0.17 for sand and silt. These values are lower than those observed in this study with $0.63,0.61$ and 0.54 for sand, clay and silt, respectively (Table 6). On the other hand, Nanni [53] found $\mathrm{r}^{2}=0.52$ for sand with bands 1,5 and 7 and, 0.67 for clay with bands 1, 3, 4, 5 and 7. The equations for SC, CEC (band 7) and V\% (band 1) showed the smallest numbers of variables. $\mathrm{OM}$ and $\mathrm{m} \%$ had 2 variables and low levels of determination coefficient $(<0.46)$ (Table 6). These values were similar to those obtained by Nanni [53] whom concluded that these equations can generate errors in estimation of attribute. Coleman et al. [60] with the paper titled "Is it possible to quantify soil attributes through sensors installed on space platforms?" showed data with significant but not consistent values of $r^{2}$ (from 0.1 to 0.4 for sand, silt, clay, iron, and organic matter). In this current study these values were better, mainly for sand and clay (Table 6).

Table 6. Multiple regression equations to estimate soil attributes by orbital sensor using 6 bands (TM Landsat-5).

\begin{tabular}{clc}
\hline Attributes & \multicolumn{1}{c}{ Multiple equations ${ }^{(\mathbf{1})}$} & $\mathbf{r}^{\mathbf{2 ( 2 )}}$ \\
\hline Total sand & $128.57173+(-14.26920 * \mathrm{TM} 3)+(13.13981 * \mathrm{TM} 5)+(26.11687 * \mathrm{TM} 7)$ & 0.6356 \\
Silt & $205.73234+(4.47412 * \mathrm{TM} 3)+(-2.51728 * \mathrm{TM} 5)+(-8.37651 * \mathrm{TM} 7)$ & 0.5435 \\
Clay & $699.99540+(-13.44352 * \mathrm{TM} 7)+(-12.69294 * \mathrm{TM} 5)+(13.03814 * \mathrm{TM} 2)$ & 0.6140 \\
OM $^{(3)}$ & $32.93323+(1.03425 * \mathrm{TM} 1)+(-1.21937 * \mathrm{TM} 7)$ & 0.41 \\
SC $^{(4)}$ & $794.50072+(-31.18313 * \mathrm{TM} 7)$ & 0.3466 \\
$\mathrm{~V}^{(5)}$ & $58.97640+(-2.19535 * \mathrm{TM} 1)$ & \\
& & 0.013 \\
$\mathrm{~m}^{(6)}$ & $-9.25324+(0.69115 * \mathrm{TM} 4)+(0.27464 * \mathrm{TM} 7)$ & 0.1374 \\
$\mathrm{CEC}^{(7)}$ & $1348.94022+(-50.85760 * \mathrm{TM} 7)$ & 0.4595 \\
\hline
\end{tabular}

${ }^{(1)}$ TM1, TM2, TM3, TM4, TM5 e TM7, TM-Landsat-5 Bands; ${ }^{(2)}$ Significant in $0,01 \%$ of probability; ${ }^{(3)}$ organic Matter; ${ }^{(4)}$ Sum of cations; ${ }^{(5)}$ Bases saturation; ${ }^{(6)}$ Aluminum saturation; ${ }^{(7)}$ Cation exchange capacity

Table 7 presents the criterion of punctual comparison between DV and EV as carried out for the laboratory data, where the EV were compared with the DV range extracted from [33] for each georeferenced sample. Each soil sample was evaluated individually. 
Table 7. Number of samples that used multiple regression equations spectral models (satellite spectral data) to determine soil attribute content.

\begin{tabular}{|c|c|c|c|c|c|c|c|c|}
\hline \multirow[b]{2}{*}{ Range $^{(a)}$} & \multicolumn{2}{|l|}{ Sand } & \multicolumn{2}{|l|}{ Silt } & \multicolumn{2}{|l|}{ Clay } & \multicolumn{2}{|l|}{$O M^{(c)}$} \\
\hline & $20.00^{(\mathrm{a})}$ & & $36.80^{(\mathrm{a})}$ & & $27.83^{(\mathrm{a})}$ & & $20.15^{(\mathrm{a})}$ & \\
\hline & Sample $^{(\mathrm{b})}$ & $\%$ & Sample & $\%$ & Sample & $\%$ & Sample & $\%$ \\
\hline Below & 19 & 8 & 41 & 18 & 44 & 19 & 56 & 25 \\
\hline In & 175 & 77 & 108 & 48 & 112 & 49 & 102 & 45 \\
\hline Above & 33 & 15 & 78 & 34 & 71 & 31 & 69 & 30 \\
\hline & $\mathrm{SC}^{(\mathrm{d})}$ & & $\mathbf{V}^{(\mathbf{e})}$ & & $\mathbf{m}^{(\mathbf{f})}$ & & CEC $^{(\mathrm{g})}$ & \\
\hline Range & $28.34^{(\mathrm{a})}$ & & $4.08^{(\mathrm{a})}$ & & $31.80^{(\mathrm{a})}$ & & $24.54^{(\mathrm{a})}$ & \\
\hline & Sample & $\%$ & Sample & $\%$ & Sample & $\%$ & Sample & $\%$ \\
\hline Below & 29 & 13 & 75 & 33 & 83 & 37 & 39 & 17 \\
\hline In & 113 & 50 & 18 & 8 & 53 & 23 & 120 & 53 \\
\hline Above & 85 & 37 & 134 & 59 & 91 & 40 & 68 & 30 \\
\hline
\end{tabular}

(a) Range interval of confidence, extracted from the IAC Laboratory Quality Control Programs Center of Soil Analysis [33];

(b) Number of samples (from total of 474) that were "below", "in" and "above" the proposed ranges; (c) Organic Matter; ${ }^{\text {(d) }}$ Sum of Cations; ${ }^{(\mathrm{e})}$ Base saturation; ${ }^{(\mathrm{f})}$ Aluminum saturation; ${ }^{(\mathrm{g})}$ Cations exchange capacity.

The best results were observed for sand with $77 \%$ agreement, i.e., 175 of the 227 samples tested were within the tolerance interval. CEC, SC and clay showed about 50\% agreement, followed by silt with $48 \%$. These results can be considered satisfactory, considering that even soil extractions can show error [6]. Low rates of agreement were observed for V\% and $\mathrm{m} \%$ (8\% and 23\%, respectively) (Table 7). Nevertheless, it is important to point out that the results suggest that further studies to determine elements should be carried out, as also emphasized by [56] and [61].

For the ranges suggested in the present study (Table 8), the result obtained for sand was $76.7 \%$ in the $0-20 \%$ range (very good), while the other attributes did not exceed $45 \%$ of agreement. For the interval above $41 \%$, the highest percentages were observed for $\mathrm{m} \%$, silt, SC and clay. In the $0-40 \%$ interval, only $\mathrm{m} \%$ showed a rate of agreement below $50 \%$, while agreement were $87.2 \%$ for sand, $74.9 \%$ for CEC, $74.4 \%$ for OM, $73.6 \%$ for V\%, 69.6\% for clay, and $51.6 \%$ for silt (Table 8). Correlation analysis between DV and EV were also carried out with the orbital data based on equations in table 6 (Figure 3 ). The highest $\mathrm{R}^{2}$ were obtained for sand (0.72) and clay (0.71). In the present study the regression coefficient for OM (0.35) was much lower than the values observed by [54] (Figure 3), with 0.51 . These authors [33] found for clay a correlation of 0.56. The coefficients obtained for SC and CEC were lower than the 0.64 , value reported for CEC by [54]. The coefficients of 0.52 and 0.67 respectively for the same attributes were determined by Nanni \& Demattê [50]. 
Table 8. Percentage of samples, results in the tolerance range, comparison between relative values ${ }^{\text {(a) }}$ of laboratory traditional data (real value) and the values obtained by the satellite spectral data models.

\begin{tabular}{|c|c|c|c|c|c|c|c|c|}
\hline & Sand & Silt & Clay & $\mathrm{OM}^{(\mathrm{b})}$ & $\mathrm{SC}^{(\mathrm{c})}$ & $\mathrm{CEC}^{(\mathrm{d})}$ & $\mathrm{V}^{(\mathrm{e})}$ & $\mathrm{m}^{(\mathrm{f})}$ \\
\hline Tolerance Range $^{(a)}$ & & & & & $\%$ & & 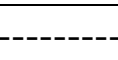 & 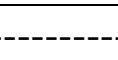 \\
\hline $0-20 \%$ & 76.7 & 26.0 & 39.6 & 44.9 & 37.4 & 44.1 & 40.5 & 13.6 \\
\hline $21-30 \%$ & 7.9 & 15.0 & 13.7 & 18.1 & 14.1 & 17.6 & 18.9 & 16.7 \\
\hline $31-40 \%$ & 2.6 & 10.6 & 16.3 & 11.5 & 9.3 & 13.2 & 14.1 & 10.5 \\
\hline$>41 \%$ & 12.8 & 48.5 & 30.4 & 25.6 & 39.2 & 25.1 & 26.4 & 59.3 \\
\hline Total (227 sample) & 100.0 & 100.0 & 100.0 & 100.0 & 100.0 & 100.0 & 100.0 & 100.0 \\
\hline
\end{tabular}

(a) Suggested by present work using the criterion: Value $=\{(\mathrm{DV}-\mathrm{EV}) / \mathrm{DV})\} * 100$ where: DV: determined in laboratory; EV: estimated by laboratory spectral data; ${ }^{(b)}$ Organic Matter; ${ }^{(c)}$ Sum of Cations; ${ }^{(d)}$ Cations exchange capacity; ${ }^{(e)}$ Base saturation; ${ }^{(\mathrm{f})}$ Aluminum saturation.

Figure 3. Scatter plot of laboratory determined soil values obtained by routine analysis (Determined Value (Y)) and estimated values obtained with the orbital spectral analysis (Estimated Value (X)).
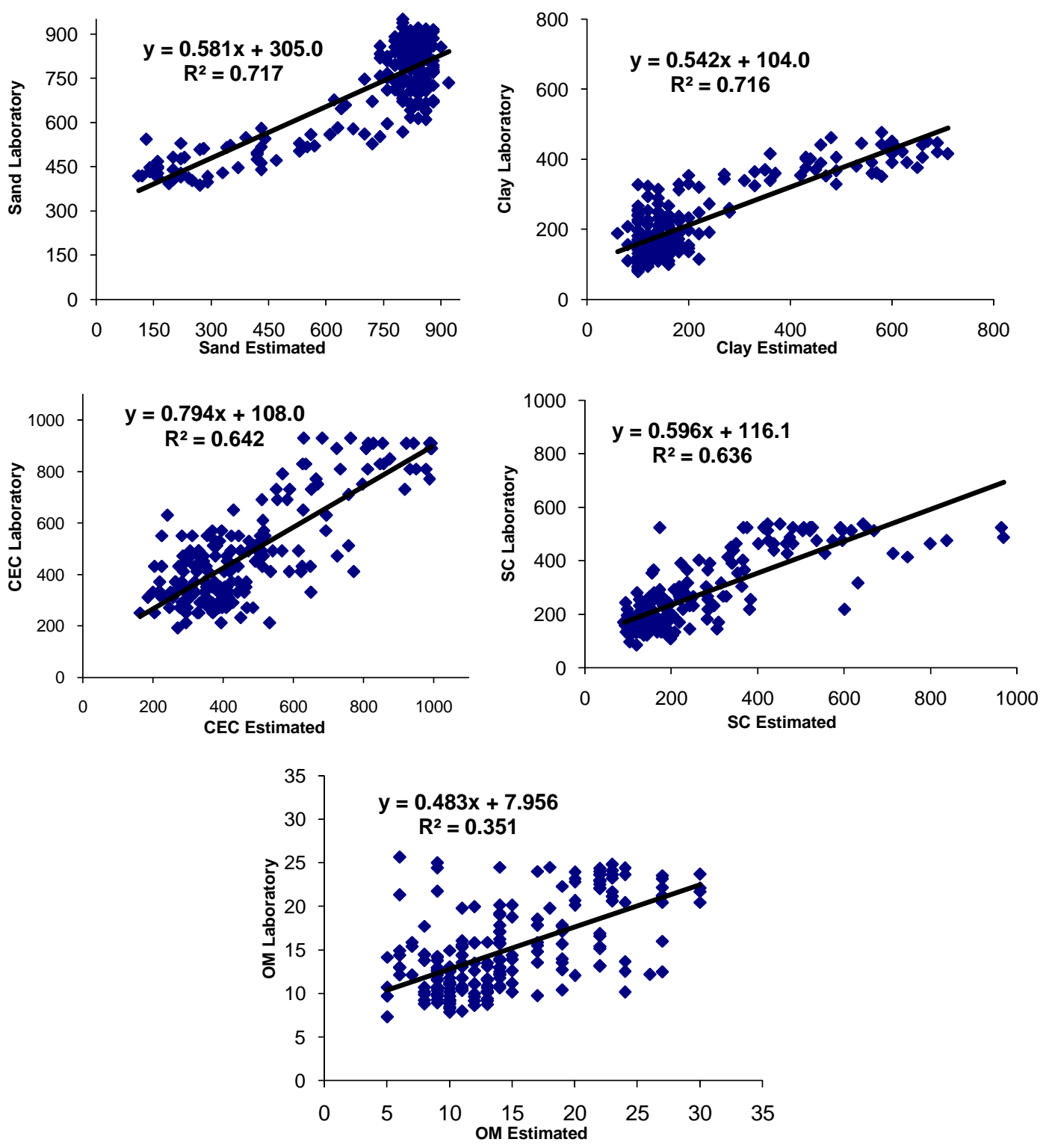
The results obtained by the orbital sensor were less consistent than those obtained with the spectroradiometric laboratory sensor, in agreement with the findings of Coleman et al. [56,60]. This was due to the fact that the laboratory data was acquired in an controlled environment, with appropriate geometry and illumination without atmospheric interference, while image data from the orbital sensor is subject to many factors which can cause interference such as soil roughness, spectral and spatial resolution, low signal-to-noise ratio, atmospheric interference, and variations in the observation and illumination angles [61]. The $\mathrm{R}^{2}$ value of 0.8 for clay, a value well above those observed in the present study, were obtained by [62], using the AVIRIS (JPL/NASA) hyperspectral sensor, thus demonstrating the improvement in sensors. These authors also pointed out that all studies involving remote sensing data indicate a direction, but the quantification requires field investigations in order to correlate the parameters obtained by image manipulation with data obtained in loco, and this is in agreement with the results presented in the current study.

\section{Conclusions}

It is possible to determine soil attributes such as clay and sand content and CEC based on reflected electromagnetic energy data obtained with a spectroradiometric laboratory sensor, as shown by the close relationship between soil attribute values estimated by equations (obtained from spectral data) and those determined by routine laboratory analysis. The most sensitive narrow-bands in modeling these attributes (using 474 observations) were B8 (1,350-1,417 nm), B10 (1,417-1,449 nm), B11 (1,449-1,793 nm), B15 (1,927-2,102 nm), B16 (2,101-2,139 nm) and B17 (2,139-2,206 nm); B7 $(975-1,350 \mathrm{~nm}), \mathrm{B} 10, \mathrm{~B} 11, \mathrm{~B} 16, \mathrm{~B} 19(2,206-2,258 \mathrm{~nm})$ and B21 $(2,258-2,389 \mathrm{~nm})$ for clay and sand, respectively.

There were $84 \%$ to $89 \%$ agreement obtained for sand content and $74 \%$ to $87 \%$ for clay between traditional laboratory variations and the estimated spectral data. Chemical parameters such as aluminum saturation and sum of cations provided significant equations with regressions coefficients $\mathrm{R}^{2}$ of 0.68 and 0.63 , respectively.

The results obtained by orbital sensor were less consistent than those obtained with the spectroradiometric laboratory sensor. It were selected for sand and silt $(3,5$ and 7$)$ the same bands of TM-Landsat-5, differing the band 2 instead of 3 for clay.

The importance of this experiment was to demonstrate that laboratory methodologies should be discussed, especially the chemical analysis. The appropriate methodology (laboratory) should be used according to the experiment objective and considering its limitations. However, it is clear that it is necessary to discuss with the scientific community about the new methodologies that should be implemented. The remote sensing method has potential and can be considered as an alternative tool for soil evaluation and conventional methods of soil analysis. Especially for physical analysis and when a large number of soil analysis are necessary. This information can guide aerial and orbital hyperspectral soil evaluation. Moreover, the evolution of this methodology may allow the collection of information and assistance in the field in real time, with sensors installed in agricultural implements. 


\section{Acknowledgements}

FAPESP (Fundação de Amparo à Pesquisa do Estado de São Paulo), for the acquisition of the spectroradiometer IRIS, (proc. $\mathrm{n}^{\circ} 95 / 6259-6$ ), for the $\mathrm{PhD}$ scholarship of the first author (proc. $\mathrm{n}^{\circ}$ 99/04325-2) and CNPq for the second author's scholarship (proc. $n .^{\circ} 300371 / 96-9$ ).

\section{References}

1. Viscarra-Rossel, R.A.; McBratney, A.B. Soil chemical analytical accuracy and costs: Implications from precision agriculture. Aust. J. Exp. Agr. 1998, 38, 765-775.

2. Plant, R.E. Site-specific management: The application of information technology to crop production. Comput. Electron. Agr. 2001, 30, 9-29.

3. Demattê, J.A.M. O pedólogo e agricultura de precisão. Boletim Informativo da Sociedade Brasileira de Ciência do Solo 2001, 26, 17-19.

4. Wetterlind, J.; Stenberg, B.; Soderstrom, M. The use of near infrared (NIR) spectroscopy to improve soil mapping at the farm scale. Precision Agric. 2008, 9, 57-69.

5. Schnug, E.; Panten, K.; Haneklaus, S. Sampling and nutrient recommendations: The future. Commun. Soil Sci. Plant Analysis 1998, 29, 1455-1462

6. Cantarella, H.; Quaggio, J.A; van Raij, B.; Abreu, M.F. Variability of soil analysis of commercial laboratories: implications for lime and fertilizer recommendations. Commun. Soil Sci. Plant Analysis 2006, 37, 2213-2225.

7. McCarty, G.W.; Reeves, J.B., III; Reeves, V.B.; Follett, R.F.; Kimble, J.M. Mid-infrared and near-infrared diffuse reflectance spectroscopy for soil carbon measurement. Soil Sci. Soc. Amer. J. 2002, 66, 640-646.

8. Viscarra Rossel, R.A.; Walvoort, D.J.J.; McBratney, A.B.; Janik, L.J.; Skjemstad, J.O. Visible, near infrared, mid infrared or combined diffuse reflectance spectroscopy for simultaneous assessment of various soil properties. Geoderma 2006, 131, 59-75.

9. Couillard, A.; Turgeon, A.J.; Westerhaus, M.O.; Shenk, J.S. Determination of soil separates with near infrared reflectance spectroscopy. J. Infrared Spectrosc. 1997, 4, 201-212.

10. Henderson, T.L.; Szilagyi, A.; Baumgardner, M.F.; Chen, C.T.; Landgrebe, D.A. Spectral band selection for classification of soil organic matter content. Soil Sci. Soc. Amer. J. 1989, 53, 1778-1784.

11. Janik, L.J.; Merry, R.H.; Skjemstad, J.O. Can mid infrared diffuse reflectance analysis replace soil extractions. Aust. J. Exp. Agr. 1998, 38, 681-696.

12. Dunn, B.W.; Beecher, H.G.; Batten, G.D.; Ciavarella, S. The potential of near-infrared reflectance spectroscopy for soil analysis-A case study from the Riverine Plain of south-eastern Australia. Aust. J. Exp. Agr. 2002, 42, 607-614.

13. Viscarra Rossel, R.A.; McGlynn, R.N,; McBratney, A.B. Determining the composition of mineral-organic mixes using UV-Vis-NIR diffuse reflectance spectroscopy. Geoderma 2006, 137, 70-82. 
14. Lagacherie, P.; Baret, F.; Feret, J.B.; Madeira Netto, J.; Robbez-Masson, J.M. Estimation of soil clay and calcium carbonate using laboratory, field, and airborne hyperspectral measurements. Remote Sens. Environ. 2008, 112, 825-835.

15. Santra, P.; Sahoo, R.N.; Das, B.S.; Samal, R. N.; Pattanaik, A.K.; Gupta, V.K. Estimation of soil hydraulic properties using proximal spectral reflectance in visible, near-infrared, and shortwaveinfrared (VIS-NIR-SWIR) region. Geoderma 2009, 152, 338-349.

16. Baumgardner, M.F.; Silva, L.F.; Biehl, L.L.; Stoner, E.R. Reflectance properties of soils. Adv. Agron. 1985, 38, 1-44.

17. Ben-Dor, E.; Irons, J.R.; Epema, G.F. Soil reflectance. In Remote Sensing for the Earth Sciences. Manual of Remote Sensing, 3rd ed.; Rencz, A.N., Ed.; Jonh Wiley \& Sons: Hoboken, NJ, USA, 1999; Volume 3, pp. 11-189.

18. Nanni, M.R; Demattê, J.A.M. Comportamento da linha do solo obtida por espectrorradiometria laboratorial para diferentes classes de solo. Revista Brasileira de Ciência do Solo 2006, 30, 1031-1038.

19. Cohen, M.; Mylavarapu, R.S.; Bogrekci, I.; Lee, W.S.; Clark, M.W. Reflectance Spectroscopy for Routine Agronomic Soil Analyses. Soil Sci. 2007, 172, 469-485.

20. Viscarra Rossel, R.V.; Cattle, S.R.; Ortega, A.; Fouad, Y. In situ measurements of soil colour, mineral composition and clay content by Vis-NIR spectroscopy. Geoderma 2009, 150, 253-266.

21. Jarmer, T.; Vohland, M.; Lilienthal, H.; Schnug, E. Estimation of some chemical properties of an agricultural soil by spectroradiometric measurements. Pedosphere 2008, 18, 163-170.

22. Morra, M.J; Hall, M.H.; Freeborn, L.L. Carbon and nitrogen analysis of soil fractions using near-infrared reflectance spectroscopy. Soil Sci. Soc. Amer. J. 1991, 55, 288-291.

23. Ben-Dor, E.; Inbar, Y.; Chen, Y. The reflectance spectra of organic matter in the visible near infrared and short wave infrared region (400-2,500 nm) during a control decomposition process. Remote Sens. Environ. 1997, 61, 1-15.

24. Sethuramasamyraja, B.; Adamchuk, V.I.; Dobermann, A.; Marx, D.B.; Jones, D.D.; Meyer, G.E. Agitated soil measurement method for integrated on-the-go mapping of soil $\mathrm{pH}$, potassium and nitrate contents. Comput. Electron. Agr. 2008, 60, 212-225.

25. EMBRAPA. Sistema Brasileiro de Classificação de solos; Embrapa: Rio de Janeiro, Brazil, 1999.

26. Raij, B.; Quaggio, J.A.; Cantarela, H.; Ferreira, M.E.; Lopes, A.S. Análise química do solo para fins de fertilidade, 2nd Ed.; Fundação Cargill: Campinas, Brasil, 1987.

27. EMBRAPA. Manual de análises químicas de solos, plantas e fertilizantes; Embrapa: Rio de Janeiro, Brazil, 1999.

28. GER. Mark V Dual Field of View IRIS Manual; Version 1.3; Geophysical Environmental Research Corp: New York, NY, USA, 1996; p. 63.

29. Henderson, T.L; Baumgardner, M.F.; Franzmeier, D.P.; Coster, D.C. High dimensional reflectance analysis of organic matter. Soil Sci. Soc. Amer. J. 1992, 56, 865-872.

30. Demattê, J.A.M.; Garcia, G.J. Alteration of soil properties through a weathering sequence as evaluated by spectral reflectance. Soil Sci. Soc. Amer. J. 1999, 63, 327-342

31. Demattê, J.A.M.; Gama, M.A.P.; Cooper, M.; Araújo, J.C.; Nanni, M.R.; Fiorio, P.R. Effect of fermentation residue on the spectral reflectance properties of soils. Geoderma 2004, 120, 187-200. 
32. Nicodemus, F.E.; Richmond, J.C.; Hsia, J.J.; Ginsberg, I.W.; Limperis, T. Geometrical Considerations and Nomenclature for Reflectance; NBS Monograph 160, US Department of Commerce, Washington, DC, USA, 1977.

33. Cantarella, H.; Abreu, C.A. Avaliação do desempenho dos laboratórios no ano de 2000. In Reunião anual do programa de controle de qualidade de laboratórios com o sistema iac de análise de solo; IAC: Campinas, Brazil, 2001.

34. Câmara, G.; Modesto Souza, R.C.; Moura Freitas, U.; Garrido, J.; Mitsuo, F., II. SPRING: Integrating remote sensing and GIS by object-oriented data modelling. Comput. Graph. 1996, 20, 395-403.

35. Thome, K.; Markham, B.; Barker, J.; Slater, P.; Biggar, S. Radiometric calibration of Landsat. Photogramm. Eng. Remote Sens. 1997, 63, 853-858.

36. Zullo, J.R. Correção atmosférica de imagens de satélite e aplicações. UNICAMP: Campinas, Brazil, 1994; p. 191, (Doutorado).

37. Tanré, D.; Holben, B.N.; Kaufman, Y.J. Atmosphere correction algorithm for NOAA-AVHRR products: Theory and application. Trans. Geosci. Remote Sens. 1992, 30, 231-248.

38. Vermote, E.; Tanré, J.L.; Iherman, M.; Morcrette, J.J. Second Simulation of the Satellite Signal in the Solar Spectrum (6S); LOA-USTL: Lille, France, 1995.

39. INPE. Tutorial Spring: Spring básico; Instituto Nacional de Pesquisas Espaciais: São José dos Campos, Brasil, 2003.

40. Jensen, J.R. Introductory digital image processing: A remote sensing perspective. Prentice Hall Publishing Co.: New York, NY, USA, 1986.

41. Demattê, J.A.M.; Huete, A.R.; Ferreira, L.G.; Alves, M.C.; Nanni, M.R.; Cerri, C.E. Evaluation of tropical soils through ground and orbital sensors. In Proceedings of 2nd International Conference on Geospatial Information Agriculture and Forestry, Lake Buena Vista, FL, USA, 2000; ERIM: Ann Arbor, MI, USA, 2000; pp. 34-41.

42. Nanni, M.R.; Demattê, J.A.M. Spectral reflectance methodology in comparison to traditional soil analysis. Soil Sci. Soc. Amer. J. 2006, 70, 393-407.

43. Jackson, R.D. Spectral indices in n-space. Remote Sens. Environ. 1983, 13, 409-421.

44. Lillesand, T.M.; Kiefer, R.M. Remote Sensing and Image Interpretation; Wiley \& Sons: New York, NY, USA, 1999.

45. Garey, A.F.; Sabbagh, G.J.; Searcy, S.W.; Yang, C. An automated soil line identification routine for remotely sensed images. Soil Sci. Soc. Amer. J. 2004, 56, 865-872.

46. Huete, A.R. Soil influences in remotely sensed vegetation-canopy spectra. In Theory and Application of Optical Remote Sensing; Asrar, G., Ed.; Wiley Interscience: New York, NY, USA, 1989; pp. 107-141.

47. Fukuhara, M.; Hayasi, S.; Yasuda, Y. Extraction of soil information from vegetated areas. In Proceedings of Machine Processing of the Remotely Sensed Data, Purdue University, West Lafayette, IN, USA, 1979; pp. 242-252.

48. Garey, A.F.; Sabbagh, G.J. Estimation of soil organic matter from red and near-infrared remotely sensed data using a soil line Euclidean distance technique. Soil Sci. Soc. Amer. J. 2002, 66, 1922-1929

49. SAS Institute. Software: User's Guide; Version 8.2. SAS Institute: Cary, NC, USA, 2003; p. 291. 
50. Nanni, M.R.; Dematte, J.A.M. Quantification and discrimination of soils developed from basalt as evaluated by terrestrial, airborne and orbital sensors (compact disc). In X Simpósio Brasileiro de Sensoriamento Remoto, Foz do Iguaçu, Brazil, 2001.

51. Madeira Netto, J.S. Spectral reflectance properties of soils. Photo Interpretation 1996, 34, 59-70.

52. Huete, A.R.; Escadafal, R. Assesment of biophysical soil properties through spectral decomposition techniques. Remote Sens. Environ. 1991, 35, 149-159.

53. Nanni, M.R. Dados radiométricos obtidos em laboratório e no nível orbital na caracterização e mapeamento dos solos. Escola Superior de Agricultura “Luiz de Queiroz”, Piracicaba, São Paulo, Brazil, 2000; p. 365 (Doutorado).

54. Ben-Dor, E.; Banin, A. Near-Infrared analysis as a rapid method to simultaneously evaluate several soil properties. Soil Sci. Soc. Amer. J. 1995, 59, 364-372.

55. Malley, D.F; Yesmin, L.; Wray, D.; Edwards, S. Applications of near-infra-red spectroscopy in analysis of soil mineral nutrients. Commun. Soil Sci. Plant Analysis 1999, 30, 999-1012.

56. Coleman, T.L; Agbu, P.A.; Montgomery, O.; Gao, L.T.; Prasad, S. Spectral band selection for quantifying selected properties in highly weathered soils. Soil Sci. 1991, 151, 355-361.

57. Demattê, J.A.M.; Silva, M.L.S.; Rocha, G.C.; Carvalho, L.A.; Formaggio, A.R.; Firme, L.P. Variações espectrais em solos submetidos à aplicação de torta de filtro. Revista Brasileira de Ciência do Solo 2005, 29, 317-326.

58. Chang, C.W.; Laird, D.A.; Mausbach, M.J.; Hurburgh J.C.R. Near-infrared reflectance spectroscopy principal components regression analysis of soil properties. Soil Sci. Soc. Amer. J. 2001, 65, 480-490.

59. Sayes, W.; Mouazen, A.M.; Ramon, H. Potential for onsite and online analysis of pig manure using visible and near infrared reflectance spectroscopy. Biosyst. Eng. 2005, 91, 393-402.

60. Coleman, T.L.; Agbu, P.A.; Montgomery, O.L. Spectral differentiantion of soils and soil properties: is it possible from space plataforms? Soil Sci. 1993, 155, 283-293.

61. Ben-Dor, E. Quantitative remote sensing of soil properties. Adv. Agron. 2002, 75, 173-243.

62. Baptista, G.M.M.; Madeira Neto, J.S.; Carvalho Junior, O.A.; Martins, E.S. Mapeamento dos teores de argila de solos tropicais, por meio de dados de sensoriamento remoto hiperespctral (compact disc). In 27 Congresso Brasileiro de Ciência do Solo, Brazil, 1999.

(C) 2010 by the authors; licensee MDPI, Basel, Switzerland. This article is an Open Access article distributed under the terms and conditions of the Creative Commons Attribution license (http://creativecommons.org/licenses/by/3.0/). 